\title{
Survival Strategy of Street Traders (PKL) in Nusukan Market Surakarta
}

\author{
Betty Gama, Yoto Widodo, and Hariyanto \\ Universitas Veteran Bangun Nusantara Sukoharjo \\ Sukoharjo, Indonesia \\ bettygama_62@ymail.com
}

\begin{abstract}
The street traders (PKL) became one of the mostcomplicated issues facing almost any growing city. The street traders as a real community presents in the urban society have a color of social interaction, such as forms of cooperation, competition and conflict. The dynamics of street traders community activities in urban society also portray the dynamics of socio-economic life of urban society. PKL Community in the Nusukan Market Surakarta, who are members of PedagangKulinerNusukan Nusantara trying to maintain the existence ofsurvival in the midst of emerging modern market competition. The purpose of this research is to know the survival strategy of street traders in Nusukan Market in the midst of increasingly tight of trade competition and how the carrying capacity of space environment, networking and cooperation of street traders with the Government of Surakarta City. The research method used descriptive research type using qualitative data, collected data such as opinions, responses, information, concepts and explanation in the form of description in expressing the problem. Data analysis used is qualitative descriptive. The research location is located in Nusukan Market Surakarta with research subject of the street traders (PKL), who sell at night. Data sources are primary and secondary data. The collecting data technique through interview, observation, literature study and content analysis. The data analysis model uses interactive analysis from Milles and Heberman. The results of the research show that street traders have a survival strategy using social capital, such as social norms, social networks and trust.
\end{abstract}

Keywords-street traders (PKL), Nusukan Market Surakarta, survival strategy

\section{INTRODUCTION}

One of the informal sectors that many people do is street traders (PKL). Street traders doing commercial activities on the streets, which should be destined for pedestrians. The existence of street traders is often rejected and even no legal protection at all. Street trader (PKL) is a problem, because it disturbs motorists, using roads and pedestrians, which cause those public spaces cannot be utilized by its users well, according to its function. As stated by McGee and Yeung, street traders have the same meaning as hawkers, defined as those who offer goods and services for sale in a place of public sphere, especially on the street and pedestrian [1]. According to the worst viewpoint, street traders are viewed as parasites and crime sources belonging to lower classes or simply regarded as irrelevant jobs. While accordingto the best point of view, they are seen as victims of the lack of job opportunities in the city and the last choice of employment opportunities for many people, in order to avoid the predicate of unemployment.
Street traders (PKL) in Local Regulation Number 8 of 1995 issued by the Government of Surakarta are those who conduct business or service in a public place, whether using or not using something in conducting business activities, with the characteristics: performed freely dependent on local resources, as family businesses and small-scale, labor-intensive and adaptive businesses, non-formal skills, unstructured competitive market. Street traders in this study are street traders, who sell or trade in Nusukan Market Surakarta. Business conducted by street traders at 17:00 to 22:00 pm along the road in front of Nusukan Market. They sell fried foods, bread, rice rames, chicken satay, soto and so on Nusukan Market is one of traditional market at Surakarta City. The traditional market according to Nasution in Wardoyo is a traditional market place (hereditary), where sellers and buyers meet, in which the goods traded depends on the buyer's demand, the set price is an agreed price through a process of bargaining, traders as producers offer prices slightly above the standard price [2].

But if observed more carefully and observant, the activities carried out by street traders are full of uniqueness and interesting to note. One of them is how these street traders survive in the midst of global competition. At first, the existences of street traders are to enliven the atmosphere Nusukan Market Surakarta at night, so that the market becomes crowded. Although they are selling with carts, they do not want to be called street traders (PKL) and they consider themselves as Nusantara Nusukan Culinary Traders (PedagangKulinerNusukan Nusantara). The term of Nusantara Nusukan Culinary Traders is used to enliven the culinary atmosphere of Surakarta City in the north, especially Surakarta is known as Culinary City. The purpose of this study is to explain how the carrying capacity of the space environment, networking and cooperation of street traders and association of street traders, in order to survive.

Strategy is a very important thing is owned by anyone to survive, for example, maintaining the continuity of a business Snel and Staring in Resmisuggests that the survival strategy is a series of actions, selected according to the standards by individuals and socially poor households [3]. The capital structure of the informal sector, including street traders has an important role in terms of survival strategies. The capital structure includes: financial capital, physical capital, ecological capital, human capital and social capital. This capital structure implies that humans are social animal, who live in mutual need and help. Therefore, the capital structure can be formed 
through familial ties, regional ties and neighboring ties [4]. Meanwhile, Putnam defines social capital by referring to "the features of social organization, such as norms, social networks, and trusts, which facilitate coordination for something that benefits can be perceived together (mutual benefit) [5].

The emergence of the informal sector, especially street traders, is a manifestation of the socio-economic aspirations of society, who have not benefited from the growth of the informal sector. They create their own business mechanisms among the lower society. It is a reality that low- and middleincome people go shopping on street traders, in order to meet their consumerism needs. Meanwhile, only high-income people are able to shop in formal shopping places. Therefore, the presence of the informal sector in this context should be responded positively with all its consistency.

\section{RESEARCH METHOD}

This study uses qualitative descriptive approach, which seeks to express and understand the realities that exist in the field of research in accordance with real conditions. The object of this research are street traders (PKL), who sell in front of Nusukan Market Solo and they are joined in PaguyubanPedagangKulinerNusukan Nusantara with number of respondents are 20 street traders (PKL). The type of data used is primary and secondary data. Data collection techniques used questionnaires, interviews, observations and documentation. Data analysis technique uses the interactive analysis method from Miles and Huberman [6].

\section{RESULT AND DISCUSSION}

In order to survive, the street traders of PasarNusukan start their business from 17.00 until 22.00 WIB (local time) by selling food and beverages. Half of the respondents (10 street traders) stated that this low income is felt to be able to support the economic life of households and the others said they cannot live the economic life of the household. These conditions make the street traders more active to make various efforts to survive in the midst of increasingly fierce competition.

The results show that $95 \%$ of street traders manage their own businesses conducted with their husbands, wives and children, while the rest have helpers. They want to do trading activities every night. A total of 6 traders $(30 \%)$ said they sell every night and the remaining 14 people $(70 \%)$ say they do not sell, if there is an urgent need. Generally, street traders try to sell every night, but at certain times such as family needs, death or other necessities, they will close their business within a certain period of time. Furthermore, to attract the attention of buyers, street traders using outdoor media. As an outdoor media, carts are used to place goods, which is decorated according to the name of the goods that being sold. In addition, street traders also use banners to attract buyers. From 20 street traders, there is only one street vendors, who use facebook as a media campaign, but the results are also not reliable. Not all carts used by street traders are their own carts. A street traders named Rina, who sells martabak for 4 years said:

The capital to sell matabbak is very high. Cart and matabbak equipment requires 15 million Rupiah at that time. I can make matabbak, because I used to work with people who sell matabbak. Now I can make matabbak and I live independently. Daily net profit ranges from $\mathrm{Rp}$ 60.000 , - to $\mathrm{Rp} 70,000$, - (Interview with Rina, September6 $\left.^{\text {th }}, 2017\right)$.

In addition, there is a street trader who has a boss, so every day she/he has to deposit the earnings to the boss. The street trader named NurRohman has just opened a business for 6 months by selling onde-onde and donut. The effort was done because he has a boss (NurRohman calls the person who helped sell his food as boss).

Every night, I deposit money to the boss. As long as I trade here, the highest deposit is three hundred thousand rupiah and the lowest one hundred and eighty thousand rupiah. As long as I trade here, the highest deposit is three hundred thousand rupiah and the lowest one hundred and eighty thousand rupiah. The size of deposit depends on the circumstances.... (Interview with NurRohman, September $\left.6^{\text {th }}, 2017\right)$.

Street traders who are members of the PaguyubanPedagangKulinerNusukan Nusantara conduct trading activities until at $10 \mathrm{pm}$. As traders who joined in the group, the existence of street traders also received attention from the PaguyubanPedagangKulinerNusukan Nusantara. The concern of the PaguyubanPedagangKulinerNusukan Nusantara to its members, such as the provision of carts. It is the duty of Jonet and EkoEndratno as the paguyuban administrator to release the carts everyday, which are placed behind the market and then brought to the front of the market starting at 15.3016.00 WIB (local time). Furthermore, after the street traders finished selling, then the cart will be returned again behind Nusukan Market (Interview with Jonet and EkoEndratno, August 18, 2017). As Jonet stated below:

Every afternoon at 15.30 WIB, I released the cart from behind of the market. I pushed the cart and put it in front of the market. If all traders do trading activities, then there are 20 carts I released. I pushed the cart as requested. After the traders had finished, I pushed the cart back to be placed behind this market.

Furthermore, Jonet also explained that the high cost bill is not only caused by cart problems, but also due to other infrastructure such as placement of floor mats as the buyer seats. In addition, also due to the contribution that must be deposited to the DinasPasarNusukan Solo. Difficulties to gain big profits make the street traders survive with the social capital they have. Referring to Putnam on social capital relating to norms, social networks and trust, the survival strategy of street traders in Nusukan Market can be explained as follows [5]:

First, social norms. Norms are rules inherent in a social relationship that uses as the control of an activity. Social norms are generally not written. In the society, these unwritten social norms are only remembered, absorbed, and practiced in the interaction between members of a community group. Norms relate to the rules among fellow street traders and how those rules can make the street traders survive. Although the status only as street traders, but the street traders are merchants, who adhere to the regulations that apply both issued by 
DinasPerdagangan Kota Surakarta and DinasPasarNusukan. For example about the cost of electricity, water services, parking carts, and so forth.

Second, social networks. These social networks are a regular, consistent and long-lasting social relationship, in which the relationship involves not only two individuals, but also many individuals. Social network that is done by street traders is to become a member of PaguyubanKulinerNusukan Nusantara. Joining that organization makes PKL traders feel safe, comfortable, and get protection from organzation. The duration of street traders opening a business influence on the social network that has been done since the establishing of the PaguyubanKulinerNusukan Nusantara in 2010. Therefore, merchant street vendors have recently opened a business in Solo Nusukan Market. Therefore, street traders have recently opened a business in Nusukan Market Solo. According to Mr. YC Bambang, BSC (interview, September 29, 2017) as Head of Nusukan Market, the presence of culinary traders intended to enliven the Nusukan Market at night, so that the market is crowded.

Third, trust. Trust is an awakening of social relations, in which there are rules that can be negotiated, in the sense that there is an open space of the rule to achieve the expectation that it wants to achieve. Trust built by street traders by providing the best service to customers and other people associated with it. Good manners with good words are a form of respect to honor customers and a friendly attitude needs to be done to attract attention.

Until now, street traders (PKL) of Nusukan Market are not included as one of the arrangement zone of street traders by City Government. Even the Street Traders agency of Trade Service (Seksi PKL DinasPerdagangan) has not made the Nusukan Market area as a street traders that needs to be managed, in order to look neat and clean (Interview with $\mathrm{Mr}$. DidikAnggono, S.Hut.,M.Si, as Head of Street Traders). This situation makes street traders feel less attention from the government and also high tax costs every night. On the other hand, although the street vendors received less attention from the Government of Surakarta City (Trade Service), but on the contrary the efforts made by street traders to get special attention from the Nusukan Market Service. Special attention is addressed by street traders, such as the provision of electricity, waste bins, water and parking carts behind the market.

\section{CONCLUSION}

The street traders (PKL) of food and beverages at Nusukan Market do not have other capabilities, but try to keep preserving their business. Social capital owned by street traders becomes a weapon to survive. The first social capital is the norm. The PKL follow and obey the rules imposed by the Dinas Pasar Nusukan dan Paguyuban Pedagang Kuliner Nusukan Nusantara. In addition, they also show good behavior by upholding charity, courtesy, mutual cooperation and so on. The second social capital is trust. The PKL are honest and friendly to both buyers and others. This is done so that the communication will continue and keep going. The third social capital is social networks. The PKL are member of the Paguyuban Pedagang Kuliner Nusukan Nusantara, which aims to gain security and protection during their business as street traders.

\section{ACKNOWLEDGMENT}

Thank you to the Directorate of Research and Community Service, General Directorate of Research and Development at the Ministry of Research, Technology and Higher Education, who has funded this research through the Competitive Grants Research Program of 2017 (Penelitian Hibah Bersaing Tahun2017).

\section{REFERENCES}

[1] Mc.Gee,T.G and Yeung,Y.M. 1977. Hawkers In South East Asian Cities:Planning for The Bazaar Economy, International Development ResearchCentre, Ottawa, Canada. pp.25.

[2] Wardoyo, Ardyan Jefri. 2011. Respon Masyarakat Terhadap Keberadaan Pasar Tradisional dan Pasar Modern di Kelurahan Kauman Kecamatan Nganjuk Kabupaten Nganjuk. Portal Tugas Akhir. Bangkalan: Universitas Trunojoyo. Tidak diterbitan. http://pta..ac.i/Program Studi Sosiologi, Universitas Trunojoyo. 8 Oktober 2014.

[3] Resmi, Setia. (2005). Gali Tutup Lubang Itu Biasa: Strategi Buruh Menanggulangi Persoalan dari Waktu ke Waktu . Bandung: Yayasan Akatiga. pp.6.

[4] Suwartika, R 2003. Struktur Modal Usaha dan Fungsi Modal Sosia dalam Strategi Bertahan Hidup Pekerja Migran di Sektor informal. Studi Kasus Kecamatan Pelabuhan Ratu dan Kecamatan Cisaat, Kabupaten Sukabumi, Provinsi Jawa Barat. Skripsi. Bogor: Jurusan Sosial /ekonomi Pertanian Fakultas Pertanian Institut Pertanian Bogor.

[5] Putnam, RD. 1993. The Prosperous Community: Social Capital and Public Life. The American Prospect No.13.

[6] Miles, M. B. \& Huberman, A. M., 1984: Qualitative Dato Analysis: A Sourcebook Of New Method. Beverly Hills, CA: Sage Publications, Inc. pp.23. 